\title{
Betimleyici Çeviri Araştırmaları Çerçevesinde Furûğ Ferruhzâd'ın “Günah” Adlı Şiirinin Türkçe Çevirilerinin Analizi*
}

\author{
Esin EREN SOYSAL**
}

$\ddot{\mathrm{O} z}$

Modern İran Edebiyatının önde gelen kadın şairlerinden Furûğ Ferruhzâd'ın “Günah” adlı şiir ile edebiyat hayatına girmiştir. Şair ataerkil bir toplumda bu şiirle birçok tepki toplamış ancak şiir yazmaktan vazgeçmeyerek, kısacık hayatına Esir, Duvar, İsyan, Bir Başka Doğuş ve İnanalım Soğuk Mevsimin Başlangıcına adlı beş şiir kitabı sığdırmıştır. Ünü ülke dışına da yayılmış ve şiirleri birçok dile tercüme edilmiştir. Yapılan bu tercümeler esnasında hedef dil yapısına göre birtakım değişimler meydana gelmiştir. Bu bağlamdan yola çıkarak şairin "duvar" adlı ikinci şiir kitabında yer alan "Günah” şiiri Gideon Toury tarafından geliştirilen "Betimleyici Çeviri Araştırmaları" yöntemi doğrultusunda kuramsal bir çerçeve içerisinde ele alınmıştır. İncelemede ele alınan "günah" şiirinin Fahri Özdemir, Makbule Aras ve Haşim Hüsrevşahi olmak üzere üç çevirmen tarafından yapılan çevirileri "kabul edilebilirlik" ve "yeterlilik" açısından incelenmiştir. Çeviriler biçimsel ve üslup yönünden değerlendirilmiş, kuram doğrultusunda kaynak ve hedef metnin konumuna göre saptamalar yapılmıştır. Çevirmenlerle yapılan görüşmeler "Betimleyici Çeviri Araştırmaları"nda öne sürülen süreç öncesi çeviri normları dahilinde ele alınmıştır ve bunlar incelemede yönlendirici olmuştur.

Anahtar Kelimeler: Furûğ Ferruhzâd, Gideon Toury, Betimleyici Çeviri Araştırmaları, Şiir Çevirisi, Farsça Çeviribilim.

\footnotetext{
* Bu makale, Furûğ Ferruhzâd'ın Türkçe Çevirilerinin Şekil, Anlam ve Üslup Açısından Değerlendirilmesi adlı (Ankara Üniversitesi, SBE, Ankara, 2019) yayımlanmamış doktora tezinden üretilmiştir.

** Arş. Gör. Dr. Karamanoğlu Mehmetbey Üniversitesi, Yabancı diller Yüksekokulu, Mütercim Tercümanlık Bölümü, Farsça Mütercim-Tercümanlık A.B.D.

Elmek: esineren1336@hotmail.com https://orcid.org/0000-0002-9957-3452.
} 


\title{
Analysis of Turkish Translations of Forough Farrokhzad's Poem Titled "Sin" in the Framework of Descriptive Translation Studies
}

\begin{abstract}
Forough Farrokhzad, one of the leading female poets of Modern Iranian Literature, started her literary career with a poem entitled "Sin". In a patriarchal society, the poet had many negative criticisms about this poem but she did not give up writing poems. She managed to write five poetry books in her short life. The books are: The Captive, The Wall, Rebellion, Another Birth, Let Us Believe in The Beginning of The Cold. Her reputation also has spread out of the country and her poems have been translated into various languages. Her poem "Sin" is included in her second book named "The Wall". This Poem has been discussed in the theoretical framework within the methods of "Descriptive Translation Studies" developed by Gideon Toury. Fahri Özdemir, Makbule Aras and Haşim Hüsrevşahi, are three of the translators who translated the poem "Sin", translations of which have been analyzed in terms of "acceptability" and "adequacy" in detail. The translations have been evaluated formally and stylistically. On the basis of the theoretical framework, inferences have been made for the location of the source and target text. Interviews with translators have been dealt within the preliminary norms proposed in "Descriptive Translation Studies" and these have been a guide for the analysis.
\end{abstract}

Keywords: Forough Farrokhzad, Gideon Toury, Descriptive Translation Studies, Poetry Translation, Persian Translation Studies. 


\section{Extended Summary}

In the study, the Turkish translations of Forough Farrokhzad's poem "Sin" based on the "Descriptive Translation Studies" approach, in which Gideon Toury adopted the target culture and text-oriented translation method, will be examined comparatively.

Makbule Aras (2008), Haşim Hüsrevşahi (2009/2014), Fahri Özdemir (2017), and their translations will be discussed as target texts in our evaluation in terms of shape, style and content based on the principle of description. It will be determined to what extent the source text is translated into Turkish in terms of shape, meaning and style and at what levels the translation occurs. Descriptive translation research is an approach developed by Gideon Toury based on the theory of the "Polysystem" introduced by Itamar Even-Zohar in the 1970s. "Polysystem" is the translation theory developed by the Israeli scientist Itamar EvenZohar in the 1970s, influenced by Russian formalists who worked in the 1920s. "Polysystem" opposes acting from a preliminary concept when translating, based on the target language / culture as the starting point in translation. Gideon Toury, who advocates that the translation has a function and position in the target language, also tried to address the position of translations in target literature and followed a descriptive way. Gideon Toury believes that translations have a position and function in target literature, such as texts in source literature. Therefore, based on the Even-Zohar's "Polysystem" Theory, he stated that the translations have a position and function in the literary polysystem specific to the target literature.

He argues that this function should be determined by the norm. Toury sees translation as an activity managed by norms; these norms determine the equivalence of translation. Toury states that these norms that guide translation should be examined in two ways:

1- Conducting a textual translation analysis, which includes examining the shifts of words detected during the comparison of source and target texts. 
2- Review of other texts such as criticism of the translation texts, foreword, afterword or interviews with translators

Toury examines the norms that determine each stage of translation in two main groups in descriptive translation studies. He calls these norms "initial norms" and "operational norms". Initial norm: It is the norm that provides information on whether the translator has made the translation directly from the source text or has used an intermediate language during the translation. Operational norm: The norm that shows what kind of decisions the translator makes during the translation act.

The poem "Sin", which will be discussed in the context of theory evaluation, is included in Forough's second poetry book called "The Wall". This poem, which brought the poet into the world of literature, consists of twenty-four verses. A $\sin$ is mentioned in this poem. However, the poet does not have any regrets about committing this sin. In the study, the translations of three different translators were evaluated morphologically, semantically, syntactically. In the study, while translators transfer the source text to the target text, it was determined that they made some additions and subtractions to make the source text feel the same effect in the target reader. However, it was determined that these changes both distorted the meaning of the source text and did not provide integrity in the target text. Each translator can make additions and deductions caused by two language differences, but this should not disturb the meaning of the text. When the translation works compared in the study are examined, the translator must make some preparations before starting to translate the source text. It has been observed that these preparations should be made in the form of obtaining information about the author of the source text, knowing which trends were influenced, determining whether the events in his life were reflected in his work, and obtaining information about the period in his works, if any. 


\section{Giriş}

Bu çalışmada Furûğ Ferruhzâd'ın şiirlerinin, ilgili çeviri kuramı aracıl1ğıyla, farklı çeviriler ile sözdizimsel, biçimbilimsel ve anlambilimsel açılardan kıyaslanarak çözümlenmesi amaçlanmaktadır.

Çalışmada Gideon Toury'nin hedef kültür ve metin odaklı çeviri yöntemini benimsediği "Betimleyici Çeviri Araştırmaları" yaklaşımı esas alınarak Furûğ Ferruhzâd'ın "Günah" adlı şiirinin Türkçe çevirileri karşılaştırmalı olarak incelenecektir. Betimleme ilkesi temelinde şekil, üslup ve içerik bakımından yapacağ1mız değerlendirmede hedef metinler olarak Makbule Aras (2008), Haşim Hüsrevşahi (2009/2014), Fahri Özdemir (2017), çevirileri ele alınacaktır. Kaynak metnin şekil, anlam ve üslup açısından ne düzeyde Türkçeye aktarıldığı ve çeviride hangi düzeylerde kayıp meydana geldiği saptanacaktır.

\section{Kavramsal çerçeve}

\subsection{Betimleyici Çeviri Araştırmaları}

Betimleyici çeviri araştırmaları, 1970'li yıllarda Itamar Even-Zohar tarafindan öne sürülen "Çoğuldizge" kuramını temel alarak Gideon Toury tarafından geliştiren bir yaklaşımdır. Öncelikle "Çoğuldizge" kuramını ele almak gerekirse, "Çoğuldizge” 1920’li yıllarda çalışmalar yapan Rus formalistlerden etkilenerek 1970’li yıllarda İsrailli bilim adamı Itamar Even-Zohar tarafindan geliştirilen çeviribilim kuramıdır. Even- Zohar, çoğuldizgeyi "Birbiriyle kesişen ya da zaman zaman örtüşen, farklı seçeneklerden yararlanan, fakat birbirine bağımlı, yapılandırılmış, bir bütün oluşturan çoklu bir dizge" (Mınday 2008:109) şeklinde tarif eder. "Çoğuldizge", çeviride çıkış noktası olarak hedef dili/kültürü temel alarak "çeviri yaparken önsel bir kavramdan hareket etmeye karşı çıkar. Dolayısıyla kuralcı hareket etmekten kaçınır. Bu bağlamda, hedef metinler arasında bir ayrım gözetmeksizin metni kuramsal düzlemde irdelemeye çalışır" (Yücel 2007:154). Çevrilmiş metni kaynağından ayrı biçimde irdeleyebilmek için metnin oluşum bağlamlarını betimlemek gerekir. Yani bir kültür bağlamında düşünüldüğünde edebiyat, felsefe, eğitim vb. 
tüm alanlar birbiriyle ilişki halindedir, zaman zaman kesişme noktalarında etkileşime de girmektedirler ve birbirlerini etkilemektedirler. Çeviri dolayısıyla edebiyat da bu bağlamda bir etkileşim ve etkileme alanına girmektedir.

Even-Zohar, çevirinin işlevsel konumunu merkezi "birincil" ve çevresel "ikincil" şeklinde adlandırmaktadır. Dizge temelinde yenilikçi olan unsurlar ve işlevler "birincil" olarak kabul edilirken, daha çok muhafazakâr özellikle unsurlar ve işlevler "ikincil”" olarak kabul edilmektedir. Even-Zohar'a göre, eğer çeviri merkez konumda ise, bu çevirinin etkin olduğu ve çoğuldizgenin merkezini biçimlendireceği anlamına gelmektedir. Böyle bir durumda çeviri edebiyat çoğunlukla yeniliklerin bir parçası haline gelmektedir ve edebiyat tarihinde gerçekleşen önemli olaylarla bağdaştırılabilmektedir. Böylece kaynak eserlerle çeviri eserler arasında bariz bir ayrım bulunmaz ve önemli çevirileri yapan kişiler, başta gelen yazarlar konumuna gelebilmektedir (Even-Zohar 2004:191-201).

Even-Zohar'a göre, çevirinin hedef dilde merkez konumda olabilmesi için edebiyatın belirli şartlarda olması gerekmektedir. Bu şartları şu şekilde sıralamaktadır:

1-Hedef dil genç bir edebiyata sahipse,

2-Hedef edebiyat "çevresel" ya da "zayıf" konumda ise bazı türleri "güçlü" ve "merkezi" konumda bulunan bir edebiyattan alabilir. Daha küçük uluslar daha büyük bir ulusun egemenliği altında ise,

3-Edebiyatın dönüm noktaları ve devingenliği artık yeni kuşak için geçerli değilse (Munday 2008: 110).

Çevirinin hedef dilde bir işlevinin ve konumunun olmasını savunan "Çoğuldizge” kuramıla Gideon Toury de hedef edebiyatta çevirilerin konumunu ele almaya çalışmış ve betimleyici bir yol izlemiştir.

Gideon Toury çevirilerin kaynak edebiyattaki metinler gibi hedef edebiyatta bir konumu ve işleyişi olduğunu düşündüğünden, Even-Zohar'ın "Çoğuldizge" Kuramı"ndan yola çıkarak çevirilerin hedef edebiyata özgü yazınsal çoğuldizgede bir konumu ve işlevi olduğunu belirtmiştir. Böylece çevirilerin hedef edebiyatta kaynak metin ve edebiyatıyla bağlantılarının koptuğunu öne sürdüğü görülür. Buna bağlı olarak, betimleyici çalışmalarıı hedef metninden başlatmayı uygun görür. Uygulamaya hedef metinden başlaması, çeviribilime devingenlik kazandırmıştır (Yazıcı 2010:130). 
Çeviri hedef metin bağlamında düşünüldüğünde, hedef metin dizgesinde ortaya çıkan eksiklikler çeviri yoluyla kapatılabilmektedir, böylece hedef metin dizgesinde bir süre çevresel konumda bulunan çeviriler, zamanla hedef metin dizgesinin merkezi konumunda yer alabilmektedirler. Toury, bu bilgiler doğrultusunda hedef edebiyatta çeviriler arasında var olan ilişkileri betimlemeye yönelmiştir. Böylece hedef metinlerdeki çeviri anlayışını saptamaya çalışmaktadır. Ancak hedef odaklı çeviriyi, hedef kültür ve edebiyat dizgesindeki işleviyle ele aldığından, bu işlevin "doğru” ya da "yanlış" olarak değerlendirilmemesi gerektiğini düşünmektedir.

Toury bu değerlendirmeleri öne sürdüğü kuramla nasıl ele alınacağını üç aşamalı bir metot önererek incelemektedir, bu doğrultuda Toury'ye göre Betimleyici Çeviri Araştırmaları yöntemi üç aşamadan oluşur:

1- Çeviri metnin hedef kültür dizgesindeki konumunu belirlemek ve çeviri metnin kabul edilebilirliliğini ve yeterliliğini gözden geçirmek.

2- Kaynak ve hedef metinler karşılaştırılarak deyiş kaydırmalarını saptamak, her iki metinden seçilecek ikili metin birimleri arasındaki ilişkileri betimlemek ve altta yatan çeviri kavramına ilişkin genellemeye varmaya çalışmak

3- Gelecekte çeviri yaparken alınan kararlarda yararlanılabilecek sonuçlara varmak. Kaynak ve hedef metin için çeviri sürecini yeniden oluşturmak (Munday 2008:112).

Toury normu, "Bir topluluk tarafından- doğru ya da yanlış, yeterli ya da yetersiz- belirli durumlara uygun ve bunlara uygulanabilir performans talimatlarına göre paylaşılan genel değer ve fikirlerin çevirisi” olarak değerlendirmektedir (Toury 1995:55). Toury, çeviriyi yönlendiren bu normların iki şekilde incelenmesi gerektiğini belirtmektedir:

1- Kaynak ve hedef metin karşılaştırılması sırasında saptanan deyiş kaydırmalarının incelenmesini içeren metinsel bir çeviri incelemesinin yapılması.

2- Çeviri metinlerine yapılan eleştiri yazıları, önsöz, sonsöz ya da çevirmenlerle yapılan söyleşiler gibi diğer yazıların incelenmesi (Tahir Gürçağlar 2011:122).

Toury'nin normları betimleyici çeviri araştırmalarında kullanmasının önemli bir sebebi, kaynak metni ikinci konumda bırakarak çevirmenin çeviri sü- 
recindeki koşullarını belirlemektir. Böylece bu koşullarla kaynak metni nasıl yorumladığı ve hedef metinde nasıl alımlandığı açıkça belirtilmeye çalışılmaktadır. Bir çevirinin değerlendirilmesi sosyokültürel koşullara göre çok yönlü bir incelemeyi gerekli kılmaktadır. Bu yüzden, çevirinin nasıl oluştuğuna dair koşulların bilinmesi, değerlendirmelerin yapılması, çeviriyi oluşturan etmenlerin neler olduğu ve etmenlerin nasıl bir çeviri yarattığını görmemize, hedef edebiyat dizgesinde nasıl bir işleve sahip olduğunu anlamamıza da yardımcı olmaktadır. Bu bağlamda kaynak odaklı bir yaklaşımın bu kuramda geçerliliği olmadığı görülmektedir.

Toury, betimleyici çeviri araştırmalarında çevirinin her aşamasını belirleyen normları iki ana grupta incelemektedir: Bunları "süreç öncesi çeviri normları" ve "çeviri süreci normları" şeklinde adlandırmaktadır:

Süreç öncesi çeviri normları: Çevirmenin çeviri süresince çeviriyi doğrudan kaynak metinden yapıp yapmadığına ya da bir ara dil kullanıp kullanmadığına dair bilgiler veren normdur. Ayrıca kaynak metne ve kültürüne ilişkin ölçütler içeren bir çeviri politikasının olup olmadığına dair de bilgiler vermektedir. Toury çeviri politikasını şu şekilde tanımlamaktadır (Toury 1995:54-56): "Çeviri politikası belirli bir süreçte bir kültüre/dile çeviri yoluyla aktarılacak eserlerin seçimini, hatta tek tek yazıların seçimini içerir. Söz konusu seçimin rastgele yapılmadığı bulgulandığı sürece böylesi bir politikanın var olduğu düşünülür. Tabii bazı alt grupların metin türlerine ilişkin ya da o grupta aracılık görevi üstlenen öznelerin ve grupların (farklı yayınevlerinin) birbirinden farklı politikaları olabilir. Bu özneler ve yaptıkları seçimler arasındaki arayüz, çeviri politikasının izlerinin sürülebileceği verimli bir alandır.”

Bu norm ayrıca çeviride etkili olan, metnin biçemi, dönemi, türü, yazarın edebi kişiliği hakkında bilgileri edinmemizi sağlamakta, ayrıca kişi ya da yayinevlerinin çeviri süreci üzerinde herhangi bir etkisi olup olmadığını değerlendirmemize olanak sağlamaktadır.

Çeviri süreci normları: Çevirmenin çeviri edimi sırasında ne tür kararlar aldığını gösteren normlardır. Bu normların incelenmesi, metinler üzerinde yapılan detaylı çözümlemelerle gerçekleştirilmektedir. Çevirmenin çeviri sırasında neyi aynen koruyacağı veya neyi değiştireceğiyle ilgili kararlarıdır. Çevirmenin dilsel malzemeyi metin içinde nasıl dağıttı̆̆ını, metni nasıl oluşturduğunu, dilsel ifadeleri ne 
şekilde kullandığını gösterir. Bu normlar kendi içinde "matriks" ve "metinsel-dilsel" normlar olmak üzere iki başlık şeklinde incelenmektedir (Toury 1995: 55-60):

1-Matriks normlar: Bu normlar çeviride kelime, deyim, atasözü gibi herhangi bir ekleme ya da atlama yapılıp yapılmadığını, cümle yapılarının, fiil zamanlarının değiş̧ip değişmediğini betimlemekte kullanılır. Kaynak dil metninde yer alan malzemenin yerini alacak hedef dil malzemesinin durumunu (çevirinin ne derece tam olarak aktarıldığını), metin içindeki yerini (ya da kaynak dil malzemesinin, hedef dil metninde nasıl dağıtıldığını) ve metnin bölümlendirilmesini yönlendirir. Yapılan eklemeler, atlamalar, yer değiştirmeler ve bölümlemede yapılan değişiklikler normlara bağımlı olmaktadır. Kaynak metnin hedef yazınına göre uygun bir şekilde ifade edilmesini sağlamaktadır.

2- Metinsel-dilsel normlar: Bu normlar, çevirmenin çeviri ediminde hedef metni oluşturacak uygun sözcük ve deyiş seçimini belirlerken devreye girerler. Kaynak metinde kullanılan dilsel ve metinsel öğelerin yerine alacak öğelerin seçimini yönlendirmektedir.

Toury, çeviriyi en az iki dil ve kültür düzeyinde iki farklı norm dizgesini içeren bir etkinlik olarak görmekte ve çeviriyi değerlendirmenin iki ana öğeden oluştuğunu belirtmektedir:

1- Çevirinin başka bir dildeki eser olması, dolayısıyla da ait olduğu dilin kültüründe ya da o kültürün bir kesiminde konumunun olması, bir boşluğu dolduruyor olmas1,

2- Çevrildiği dilde/kültürde başka bir dilde daha önce üretilmiş olup o dilin ait olduğu kültürde net bir konuma sahip olan bir metni temsil ediyor olması (Toury 1998:10-32).

Toury, bahsedilen iki ana öğeye dayanarak çeviri değerlendirilmesinde öncül bir normun ortaya çıktığını ve bu norma göre kaynak metin ve hedef metin arasında bir inceleme yapıldığını belirtmiştir. Bu incelemede kaynak metin ve hedef metnin eşdeğer olup olmadığını gözlemlemekten ziyade kaynak metne göre mi yoksa hedef metne göre mi çeviri yapıldığını ortaya koymayı amaçlanmaktadır. Çünkü betimleyici çeviri çalışmalarında, çeviri "eşdeğerlik” kavramına göre incelenmemektedir. 
Işın Bengi'nin de belirttiği gibi, Toury, “eşdeğerliliği” geleneksel anlamından farklı değerlendirmiştir: "Toury, kaynak ve hedef metin değerlendirmesinde var olan sabit eşdeğerlik anlayışından ziyade, "problem+çözüm" bağlamında oluşan fonksiyonel bir eşdeğerlik arayışına girmektedir. Tarihsel süreçte "eşdeğerliliğin" değişen bir kavram olduğunu belirterek çeviriyi somut verilerle ele alarak "kabul edilebilirlik" ve "yeterlilik" kavramlarına göre incelemiştir. Eşdeğerlilik kavramı hem anlamsal hem de dilsel açıdan daha çok kaynak odaklı bir incelemeyi gerektirmektedir. Ancak Toury'nin öne sürdüğü "kabul edilebilirlik" ve "yeterlilik" kavramları hedef metne ve kaynak metne göre değişiklik göstermektedir. $\mathrm{Bu}$ değişikliği belirlemek için Toury hedef ya da kaynak normlardan hangisinin çeviride egemen olduğuna bakarak karar vermektedir. Eğer çeviri, kaynak metninin ve kültürünün normlarıyla örtüşüyorsa, yani hedef okuyucuda yabancılık duygusu yaratmıyorsa "kabul edilebilir" bir çeviri, kaynak metninin ve kültürünün normlarıyla çatışıyorsa, hedef okuyucu alımlamada problem yaşıyorsa "yeterli" bir çeviri olarak kabul edilmektedir" (Bengi-Öner 1999:118-119).

Toury "kabul edilebilirlik" ve "yeterlilik" kavramlarını çeviri metninin etkisine göre değil, kaynak ve hedef kültüre göre seçilen normlara göre sınıflandırmaktadır. Çevirinin kaynak kültürün normlarına yakın olması, kaynak odaklı çeviri yaklaşımıyla karıştırılmamalıdır. Her ne kadar kaynak metni yaratan normlar, Toury'nin betimleyici kuramında bir yere sahip olsa da çevirilerin değerlendirilmesinde kaynak metin, araçsal bir konumdadır (Yücel 2007:165-166).

Stolze, Çeviri Kuramları adlı eserinde, betimleyici çeviri araştırmalarında ele alınan kültür kavramına değinmiş, kültürün "sözcükle, metinlerin toplamı ve bir dil topluluğunun bunlara yansıyan tasarımları" olduğunu belirtmiştir. Hedef odaklı bir yaklaşım olduğuna değinerek bazı temel ilkelerini ele almıştır (Stolze 2013:184-188):

1- Çeviriler kültürel bir gerçektir ve bir hedef kültürün nesnesi olarak kabul edilmektedir. Bu her metnin bir başka metnin çevirisi olarak kabul edilmesi gerektiği anlamına gelir. Aynı şey "sözde çeviriler" için de geçerlidir. Bir hedef kültürde bir çeviri metninin değiştirici etkisi, çevirinin işleviyle ve aynı zamanda metin özelliğiyle ortaya çıkar: "Çeviriler aslında bir hedef kültürün ihtiyaçlarını karşılamaya yöneliktir, aynı zamanda, yerleşik kalıplardan, bir düzeyde ya da daha fazla sapma eğilimi gösterirler, özellikle, herhangi bir kültür-içi çeviri an- 
layışının parçası gibi görünen kaynak metnin en azından bazı özelliklerinin sabit kalmasından dolayı. Bu eğilim çoğu zaman çevirileri, diğer metinlerden oldukça farklı hale getirir" (Toury 1995:186).

2- Bu tür betimleyici araştırmaların ön koşulu elbette uygun bir bağlamlaştırmadır ve bu da bilimsel araştırma sürecinde ortaya çıkmaktadır. Bu noktada, (alt) kültürün hangi dilde formüle edildiğinin bilinmesi nedeniyle çevirinin (alt) kültürünün zaten tanındığına ilişkin düşünce, yanıltıcı bir çıkarım olabilir, çünkü dil ile kültür arasında bire bir ilişki yanıltıcı olabilir.

3- "Varsayılan Çeviri", yani "çeviri olarak işleyen bir metin" kavramı, betimleyici çeviri araştırmaları için merkezî bir kavramdır. Çoğu kuramlar önce "çevirinin" ne olduğunu tanımlamaktadır. Bu tümdengelen bir çalışmayla bağlantılıdır. Ancak deneysel eğilim betimleyici yaklaşımla çelişmektedir. Toury bu duruma şöyle açıklık getirmektedir: "Dolayısıyla, 'tabiatı gereği' çevirisel olanı tahminen belirten herhangi varsayımsal bir tanımlama, özellikle öz açısından ifade etmek gerekirse, değiş̧kenliği -kültürlerarası farklılıklar, kültür içi varyasyonlar ve zamanla gerçekleşen değiş̧iklikler-ile nitelenen nesnenin tüm sınırların bir kereye mahsus sabitlemenin savunalamaz savını kapsar. Çalışma alanı önemli ölçüde kültürlerin ne olduğu ve çevirisel olarak neyi kabul etmek istemesi hususundaki yolu daraltmakla kalmaz, aynı zamanda bu sınırların belirlediği çalışma kısır bir döngüden ibaret olurdu" (Toury 1995:31).

Demircioğlu da, Toury'nin bu bakış açısı hakkında şöyle bir açıklama getirmiştir: "Toury'nin betimleyici yaklaşımında tarih, kuramsal alanı besleyen içsel bir öğe olarak öne çıkar. Çeviri külliyatının saptanması ve "keşif yöntemleri”yle (discovery procedures) ilgili ileri sürdüğü üç postulata (kaynak metin, aktarım ve ilişki postulaları) çeviriye tarihsel perspektiften yaklaşır. Bu bağlamda, çeviri külliyatının saptanmasında çeviri eserlerin çeviri olmayanlardan nasıl ayırt edilebileceği sorusunu ortaya atarak erek dizgede "çeviri” olarak nitelenen her eserin a priori bir şekilde tanımlanamayacağını, ancak incelenmek üzere "çeviri” olarak kabul edilmesi gerektiğini belirtir” (Demircioğlu 2016: 59-60).

4- Böyle çeviri stratejileri de çeviri süreci açısından betimleyici çeviri araştırmalarının araştırma nesnesi olur. Metin unsurları yan yana getirilerek bir metin çiftinin karşılaştırılmasıyla, çevirinin temel yapısı ortaya çıkabilir ya da bir çevirinin söz konusu olduğu saptanabilir. 
Yapılan çıkarımlar çalışmanın inceleme kısmında "günah" şiiri ile değerlendirilecektir.

\section{2- "Günah" Şiiri ve Değerlendirilmesi}

$$
\begin{aligned}
& \text { كناه }
\end{aligned}
$$

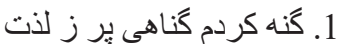

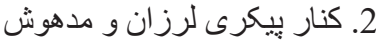

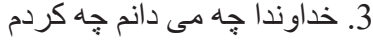

$$
\begin{aligned}
& \text { 4. در آن خلوتخه تاريكى و خاموش درد } \\
& \text { 5. در آن خلوتكَه تاريكى خاموش }
\end{aligned}
$$

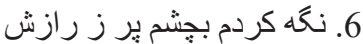

$$
\begin{aligned}
& \text { 7. }
\end{aligned}
$$

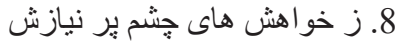

$$
\begin{aligned}
& \text { 9. در آن خلوتكه تاريكى خاموش } \\
& \text { 10. بريشان در كنار او نشستم } \\
& \text { 11. لبش بر روى لبثان دركنار هايم هوس ريخت } \\
& \text { 12. زاندوه دل ديو انه رستم } \\
& \text { 13. فرو خو اندم بكوشش قصه عثق } \\
& \text { 14. تر ا مى خو اهم اي جانانه من }
\end{aligned}
$$

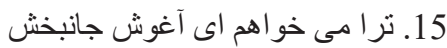

$$
\begin{aligned}
& \text { 16. ترا اي عاثقى ديو انه من أشي } \\
& \text { 17. هوس در ديدكانش شعله افروخت } \\
& \text { 18. شر اب سرخ در بيمانه رقصيد } \\
& \text { 19. تن من در ميان بستر نرم بردي } \\
& \text { 20. بروى سينه اش مستانه لرزيد }
\end{aligned}
$$

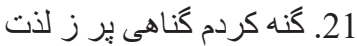

$$
\begin{aligned}
& \text { 22. در آغوشى كه كرم و آتثشين بود لَّد }
\end{aligned}
$$

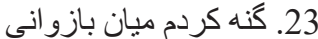

$$
\begin{aligned}
& \text { 24. كه داغو كينه جوى و آهنين بود بازي }
\end{aligned}
$$


"Günah" şiiri Furûğ'un Duvar adlı ikinci şiir kitabında yer almaktadır. Şairi edebiyat dünyasına sokan bu şiir yirmi dört dizeden oluşmaktadır. Şair toplum tarafından çizilen sınırları şiiriyle aşmaya çalışmıştır. Bu şiirde işlenen bir günahtan bahsedilmekte, ancak şair bu günahı işlemekten dolayı bir pişmanlık duymamaktadır. Hissettiği samimi, sıcak ve sevecen bir sevgilinin varlığı ve duygularının yoğunluğudur. O dönemde ataerkil bir toplumda evli bir kadının böyle cinsellik içeren erotik şiirler yazması büyük tepkilere yol açmıştır. Şaire hem ailesi hem de edebiyat çevresi farklı bir gözle bakmaya başlamıştır. Ailesi tarafından dışlanan ve zor günler geçiren şair, şiire daha çok sarılarak kendini ifade etmeye başlamıştır. Birçok ses ve kelime yinelemesiyle şiirde içsel bir ritim bulunmaktadır. Ayrıca belirli bir kafiye düzeni yer almaktadır. Sade ve akıcı bir dili olan şiirin etkili bir ifadesi bulunmaktadır.

Ghasemi-Pourgiv "Günah" şiiriyle karşı cinsle alâkalı samimî detaylar hakkında açıkça konuşarak, şairin bütün cinsel tabuları yıktığını düşünmektedir (Ghasemi-Pourgive 2010:771).

Joodaki-Vajdi "Body, Love and Maternity in Sylvia Palt anf Forugh Farrokhzad: A Study Based on Helen Cixous's Ecriture Feminine” adlı çalışmalarında, "Günah" şiiri hakkındaki görüşlerini şöyle belirtmektedirler: "Furûğ'un şiirindeki her kelime kendi kökünden habersiz taze bir anlam kazanıyor, onun çabası dilin efsanevi niteliklerini değiştirmek ve yeni bir dil öne sürmekti. Bu dili ortaya çıkarmadaki çabası, Duvar kitabındaki "Günah" şiirinde açıkça görülmektedir" (Joodaki- Vajdi 2013: 77).

Hillman "Sexuality in the Verse of Forugh Farrokzad and the Structualist View" adlı çalışmasında "günah" şiirinde cinsel bir aşk gecesinden bahsedildiğini, ancak şairin sevgilisinin cinsiyetini belirtmediğini, fakat ilk dörtlükte erkek olma ihtimalinin yüksek olduğunu ifade etmektedir. Ayrıca gerçek bir tutkunun dürüst ifadesi olarak görünen ve kimseyi incitmeyen bu anın, neden günah dolu olduğuna dair okuyucuda merak uyandırdığı düşünülmektedir. İlaveten bu şiirde ünlü İranlı şair Hafız'ın 26. gazelinin etkileri olduğunu dile getirmektedir (Hillman 1979:195).

Hajibashi, "Redefining 'Sin" adlı çalışmasında "Günah" şiirinin bir kadının bir erkekle cinsel ilişkide hissettiği duyguların başarılı bir şeklide iletimi 
olduğunu ifade etmektedir. Şairin diğer kadınların yeterince bu tecrübeyi fark etmesi ve erkeklerin hayal etmesi için günah işleyen bir kadın gibi tecrübelerini ortaya koymak için yazdığını düşünmektedir. Bir kadının çeşitli düzeylerdeki duygularını ifade edebilmek amacıyla alışılmamış sıfatlar ve betimleyici tabirler kullandığını gözlemlemektedir (Hajibashi 1988:67-71).

Diler, makalesinde Furûğ'u "Günah" şiiriyle Arendt'in görüşüne göre şöyle değerlendirmiştir: "Töreye ve geleneğe başkaldıran Ferruhzzâd, her ne kadar şiirindeki kadından hoşnutsa da toplum onu sözleriyle linç eder. Evliliğin hayal kırıklı̆̆ıyla kanatları ağırlaşan tutsak kuş sömürgeleştirildiği yerden, babasından sonra kocasının gözetimine teslim edilen cinselliğinden saldırmıştır gökyüzüyle arasına gerilen duvara. Egemen toplumun iyi halli bir üyesi olarak doğmuş olan bu esir kuş olmadığı biri, bir parvenu gibi davranmaktansa, paryalaşarak konuşan eyleme, şiire dönüşüp, kan dökücü tanrı yerine tanrıçanın sunağında kurban olmayı seçer" (Diler 2013:66).

\subsection{Kaynak Metin ile Hedef Metinlerin Karşılaştırılması}

\section{1. 1. Fahri Özdemir Çevirisi}

\section{Günah}

1. Bir günah işledim tadına doyulmayan

2. Titreyerek coşkuyla akan bir bedenin yanında

3. Ey tanrım ne yaptım ben bilmeden

4. O sessiz sedasiz kuytuda

5. O sessiz sedasiz kuytuda

6. Kayboldum gizemlerle dolu gözlerinin buğusunda

7. Ve gözlerindeki dizginlenemeyen arzularında

8. Yüreğim çaresizlik içinde atarken göğüs kafesimde

9. O sessiz sedasiz kuytuda

10. Çaresiz, perişan bir halde oturdum yanına

11. Bütün şehvetlerini döktü dudakları dudaklarıma

12. Kurtuldum acılarından kedere batmış kalbimin 
13. Fısıldadım aşk masallarını kulağına

14. Seni istiyorum ey sevgili

15. Seni seviyorum göğsü can evim olan

16. Seni istiyorum aşığım divanem

17. Arzulandı alevler gözlerinde

18. Ve coştu kırmızı şarap dans ederek kadehte

19. Oysa ben o yumuşacık yatakta

20. Kendimden geçip esir düştüm göğsünde

21. Bir günah işledim tadına doyulmayan

22. Alevlerin sardığ sıcacık bir kucakta

23. Bir günah işledim ateşli ve kindar

24. İki demirden kolun bağrında

Özdemir, yirmi dört dizelik kaynak metni, yirmi dört dize olarak hedef metne aktararak biçimsel eşdeğerliliği sağlamıştır. Kaynak metinde belirli bir kafiye düzeni varken hedef metinde bu düzen sağlanamamıştır. Çevirmen birçok yerde ekleme yaparak kaynak metne bağlı kalmamıştır. Bu eklemeler hedef dilde okunabilirliği sağlasa da kaynak metin mesajından uzaklaşmıştır.

Kaynak metnin ilk dizesinde yer alan "كنه كردم كناهى يְر ز لذت günah işledim lezzet dolu bir günah" tümcesini dizede hem "günah işledim" fiili hem de "günah" kelimesi bulunmasına rağmen çevirmen hedef metinde "günah" kelimesini çıkararak "tadına doyulmayan" şeklinde aktarmış, kaynak metinde vurgulanmak istenen "جünah" ifadesinin vurgusu hedef metinde yitirilmiştir. 3. dizede yer alan "جى" ne bileyim" soru ifadesi yazarın kendine bir sebep aramasını ifade ederken hedef metne "bilmeden" şeklinde olumsuz aktarılmıştır. 4, 5 ve 9. dizelerde " تاريك و "karanlık ve sessiz" sıfatları "sessiz sedasız şeklinde kaydırılarak yine dizenin anlamından sapılmış "karanlık" sıfatı çıkarılmış "sessiz" sıfatı pekiştirilmiştir.

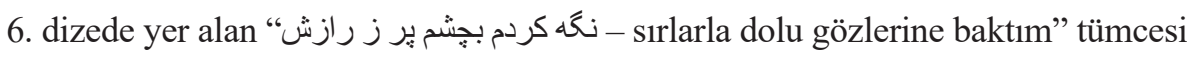
hedef metne "kayboldum gizemlerle dolu gözlerinin buğusunda" şeklinde aktarllmış "baktım" fiili "kayboldum" fiili olarak değiştirilmiş, "buğusunda" ifadesi eklenmiş, dize anlamsal olarak kaydırılmış, anlamsal bağ kopmuştur. Kaynak metnin 7. dizesi hedef metne 8. dizede aktarılmış, biçimsel olarak kaydırılmıştır. Üstelik “ ير 
نياز -istek dolu” ifadesi “dizginlenemeyen” şeklinde anlamsal olarak kaydırılmıştır. Kaynak metnin 8. dizesi ise hedef metne 7. dizede aktarllarak yine biçimsel olarak kaydırılmış ve "atarken göğüs kafesimde" ifadesi eklenmiş, "بـى تبابانه sabırsızlıkla, merakla" ifadesi "çaresizlik" şeklinde anlamsal olarak saptırılmıştır. Hedef metnin 10. dizesinde yer alan "çaresiz" kelimesi kaynak metinde yer almamaktadır, metne ekleme yapılmıştır. Kaynak metnin 12. dizesinde yer alan "اندوه دل ديو انه - divane gönlümün üzüntüsü" tamlaması hedef metne "acılarından kedere batmış kalbimin" şeklinde kaydırılmış, kaynak metin bağlamı hedef metne aktarılamamış, çevirmen kendi yorumunu katmıştır. Çevirmen kaynak metne ekleme, çıkarma ve değiştirim yapabilir, ama bu kaynak metnin mesajını zedelemeden yapılmalıdır. Kaynak metnin 15. dizesinde yer alan "جانبخش can veren" ifadesi hedef metne "can evim" şeklinde kaydırılmıştır. 16.dizede yer alan "عانقق ديو انه من" divane aşı̆̆ı̆ı” tamlaması hedef metne iki sözcük olarak "aşığım, divanem" şeklinde biçimsel ve anlamsal olarak kaydırılmıştır. 18. dizede yer alan "ve coştu" bağlaç ve fiili ile 19. dizede yer alan "oysa" zarfı kaynak metinde yer almamaktadır, ekleme yapılmıştır. 22. dizede sıcak ve ateşli” sıfatları "alevlerin sardığı sıcacık” şeklinde biçimsel ve anlamsal olarak kaydırılmıştır.

\subsubsection{Haşim Hüsrevşahi Çevirisi}

\section{Günah}

1. Günah işledim lezzet dolu bir günah

2. Titreyen esrik bir tenin yanında

3. Tanrım ne bileyim ne yaptım ben

4. O karanlık susku dolu zulada

5. O karanlık susku dolu zulada

6. Baktım gözlerine gizemleriyle dolu

7. Gözlerinin çaresiz isteklerinden

8. $\quad$ Kalbim göğsümde çırpınıp durdu

9. O karanlık susku dolu zulada

10. Yanında darmadağın oturdum

11. Dudaklarıma heves döktü dudakları

12. Deli kalbimin üzüncünden kurtuldum 
13. Aşkın öyküsünü okudum kulaklarına:

14. Seni istiyorum ey benim cananem!

15. Ey bağrı can bağışlayan, seni

16. Seni ey aşı̆̆ım benim divanem!

17. Kırmızı şarap camda oynadı

18. Gözlerinde heves yalazland1

19. Yumuşak yatakta benim bedenim

20. Göğsünde onun sarhoşça kıvrandı

21. Günah işledim lezzet dolu bir günah

22. Alevli yang1lı bir kucakta

23. Günah işledim kinci, sicak

24. Ve demirsi iki kol arasında

Hüsrevşahi, yirmi dört dizelik kaynak metni hedef metne yirmi dört dize olarak aktarmıştır. Kaynak metnin kafiye düzenine riayet etmemiş, ancak içsel ritmi sağlamaya çalışmıştır. Mümkün olduğunca kaynak metne bağlı kalmış, metnin anlam örgüsünden kopmamıştır.

Kaynak metnin 8. dizesinde yer alan "ز خو اهش هاى جشم يُر نيازش istek dolu gözlerinin arzusundan" ifadesi hedef metnin 7. dizesine kaydırılarak "gözlerinin çaresiz isteklerinden” şeklinde aktarılmış, "istek” kelimesi “çaresiz” kelimesi yerine kullanılarak anlamsal olarak kaydırılmış, yine kaynak metnin 7. dizesi hedef metne 8. dizede aktarılmış " sabırsılılıla titredi” ifadesi "çıırpınıp durdu" şeklinde kaydırılarak metnin mesajından uzaklaşılmıştır. 16.dizede yer alan "عاثق ديو انه من divane aşı̆̆ım” tamlaması hedef metne iki sözcük olarak “aş1ğım, divanem" şeklinde biçimsel ve anlamsal olarak kaydırılmıştır. 18.dizede yer alan “بيمانه- kadeh” kelimesi hedef metne “cam” olarak kaydırılmış, özel bir ifade genelleştirilmiş, bağlamdan uzaklaşılmıştır. 20. dizede yer alan " لرزيد - titredi” fiili "kıvrandı" şeklinde anlamsal olarak kaydırılmıştır. 


\subsubsection{Makbule Aras Çevirisi}

\section{Günah}

1. Günah işledim hazla dolu bir günah

2. Titreyen, mest bir bedenin yanında

3. Ey Tanrım ne yaptım bilmiyorum ben

4. $\quad \mathrm{O}$, sessiz ve karanlık inzivada

5. $\quad \mathrm{O}$, sessiz ve karanlık inzivada

6. Baktım sirlarla dolu gözlerine

7. Yalvaran gözlerindeki arzulardan

8. Kalbim takatsiz kaldı göğsümde

9. $\quad \mathrm{O}$, sessiz ve karanlık inzivada

10. Perişan, yanında oturdum

11. Arzu döktü dudakları dudaklarıma

12. Divane gönlümün sıkıntısından kurtuldum

13. Aşk masalı mırıldandım kulağına:

14. Seni istiyorum ben ey sevgili

15. Seni istiyorum ey koynu can bahşeden

16. Ey divanem, ey aşığım seni

17. Arzu alevlendi gözlerinde

18. Kırmızı şarap raksetti kadehte

19. Tenim o yumuşacık yatakta

20. Kendinden geçerek titredi onun göğsünde

21. Günah işledim hazla dolu bir günah

22. Sicak, ateşli bir kucakta

23. Günah işledim demirden

24. Ateşli, öç peşinde kollar arasında

Aras yirmi dört dizelik kaynak metni yirmi dört dize olarak hedef metne aktarmış, biçimsel eşdeğerliliği sağlamıştır. Kaynak metnin kafiye düzene riâyet etmiş, aynı ritimsel bağı sağlamıştır. Hedef okuyucu dikkate alınarak çevrilmiş; ancak kaynak metnin de anlamsal örgüsüne zarar verilememiştir. 
3. dizede yer alan "جن مناد ىم ne bileyim" soru ifadesi "bilmiyorum" şek-

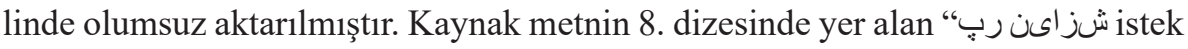
dolu" ifadesi hedef metnin 7. dizesine anlamsal kaydırılarak "yalvaran" şeklinde aktarılmış, dize farklı anlamla ifade edilmiştir. Yine kaynak metnin 7. dizesi hedef metne 8. dizede aktarılmış " دىزرل منابات ىب - sabırsılikla titredi" ifadesi "takatsiz kaldı" şeklinde kaydırılarak metnin mesajından uzaklaşılmışıtır.

\section{Sonuç}

Çalışmada Furûğ Ferruhzâd'ın "Günah adlı şiiri Betimleyici Çeviri Araştırmaları kuramı bağlamında incelenmiştir. Çalışmada üç ayrı çevirmenin çevirileri biçimbilimsel, anlambilimsel, sözdizimsel değerlendirilmiştir. Ayrıca değerlendirme yapılmadan önce çevirmenlere birtakım sorular yöneltilmiştir. İncelemeler bu sorulara verilen cevaplarla birlikte yapılmış, teori kısmında ele alınan süreç öncesi norm aşaması da yerine getirilmiştir.

Çalışmada çevirmenlerin, kaynak metni hedef metne aktarırken, kaynak metnin hedef okurda da aynı etkiyi hissetmesi için bir takım ekleme ve çıkarmalar yaptıkları saptanmıştır. Ancak yapılan bu değişimlerin hem kaynak metnin anlam örgüsünü bozduğu hem de hedef metinde bütünlük sağlamadığı tespit edilmiştir. Her çevirmen kendince iki dil farklılığından kaynaklanan ekleme ve çıkarmalar yapabilir ancak bunun metnin anlamını bozmaması gerekmektedir. Bu bağlamda en fazla ekleme çıkarma yapan çevirmen olan Özdemir'in, kaynak metnin mesajından saptığı kendi yorumunu kattığ 1 gözlemlenmiştir. Özdemir, daha çok hedef odaklı bir çeviri yöntemi izlemiştir. Kaynak metinde olmayan birtakım kelimeleri aktarım esnasında metne eklemiştir. Bu eklemeler hedef metinde okunabilirliği sağlamazken, kaynak metindeki anlam örgüsünü yansıtamamıştır. Daha çok kendi yorumunu hedef metne yansıtan çevirmen, kaynak metni yansıtmada yetersiz kalmıştır. Genel itibariyle Özdemir çevirisi, "kabul edilebilir" bir çeviridir.

Hüsrevşahi hem kaynak odaklı çeviri stratejisi uygulamıştır. Metnin biçimsel özelliklerine çok da dikkat etmeyen çevirmenin -ana dilinin Farsça olmasından dolayı- Türkçe birtakım ifade farklılıkları görülmektedir. Bazı kelimelerin anlamları tam olarak metne yansıtılamamıştır. Yine de hedef metinde şiirsel etkiyi verebilmiştir. Hüsrevşahi çevirisi kaynak odaklı bir çeviri ürünü olduğundan Toury'nin Betimleyici Çeviri Araştırmalarına göre “yeterli” bir çeviridir. 
Aras'ın daha çok hedef odaklı çeviri stratejisi uyguladığı, kaynak metin ruhunu yansıtmak için etkili kelimeler seçtiği, bazı kelimeleri pekiştirerek aktardığ1 ve tercümesinde yine hedef odaklı kalmaya çalıştığı tespit edilmiştir. Genellikle kafiye, redif ve içsel ahenge dikkat ettiği ve uygulamaya çalıştığı gözlemlenmiştir. Aras çevirisi hem hedef dilde okunabilirliği arttırdığı hem de kaynak metni omurgasını oluşturan kelimeleri değiştirmediği için Toury’nin Betimleyici Çeviri Araştırmalarına göre hem "yeterli" hem de "kabul edilebilir" bir çeviridir.

Çalışmada karşılaştırılan çeviri eserler incelendiğinde çevirmenin kaynak metni çevirmeye başlamadan önce birtakım hazırlıklar yapması gerekmektedir. $\mathrm{Bu}$ hazırlıkların daha çok kaynak metnin yazarı hakkında bilgi edinilmesi, hangi akımlardan etkilendiğinin bilinmesi, yaşamındaki olayların eserine yansıyıp yansımadığının saptanması ve eserlerinde yaşadığı dönemin etkileri varsa dönem hakkında bilgi edinilmesi şeklinde yapılması gerektiği gözlenmiştir.

Furûg Ferruhzâd'ın çevirilerinde ise çevirmenlerin, genellikle kaynak metnin yapısını aktarmaktan ziyade anlam aktarımını ön planda tuttukları, kaynak metnin duru ve anlaşılır diline sadık kaldıkları kanaatine varılmıştır. Çevirmenlerle ilgili yapılan değerlendirmeyle birlikte, bir çevirmenin kaynak metni aktarırken sadece dil bilmesinin yeterli olmadığı, her iki dile hâkim olmanın yanı sıra her iki kültürü, ifade çeşitliliklerini, gelenek ve görenekleri, inançları ve toplumsal yapıyı da bilmesi gerektiği sonucuna varılmıştır. 


\section{Kaynakça}

Bengi-Öner, I. (1999). Çeviri Bir Süreçtir... Ya Çeviribilim? İstanbul:Sel Yayıncılık,

Demircioğlu, C. (2016). Çeviribilimde Tarih ve Tarihyazımı (Doğu-Batı Ekseninde Bir Karşılaştırma). İstanbul: Boğaziçi Üniversitesi Yayınevi.

Diler, M. (2013). Hannah Arendt’ten Furuğ Ferruhzad'a Bakmak Esaretten Özgürlüğe Açılan Pencere: Furuğ Ferruhzad Şiiri. Fe Dergi 5, no. 2,59-74.

Even-Zohar, I. (2004). Yazınsal Çoğuldizge İçinde Çeviri Yazının Durumu. (Çev. Saliha Paker), Çeviri Seçkisi-2, (Derl: Mehmet Rifat), (ss. 191-201) İstanbul: Dünya Yayınları.

Ghasemi, P.- Pourgiv, F. (2010). Captivity, Confrontation, and Self- Empowerment: identity in Forugh Farrokhzad's poetry. Women's History Review, say1 19: 5.

Hajibashi, Z.(1988). Redefining ‘Sin”, Forugh Farrokhzad A Quarter- Century Later. (Edited by Michael Craig Hillmann), Literature East\&West, ss. 67.-71.

Hillman, C. M. (1979). Sexuality in the Verse of Forugh Farrokzad and the Structualist View. Edebiyat, Volume 3.

Joodaki, A.H.- Vajdi, A. (2013). Body, Love and Maternity in Sylvia Palt and Forugh Farrokhzad: A Study Based on Helen Cixous's Ecriture Feminine. CSCanada Studies in Literature and Language, Vol.6, No.3, ss. 74-77.

Munday, J. (2008). Introducing Translation Studies, 2nd Edition, Newyork: Routledge.

Stolze, R. (2013). Çeviri Kuramları Giriş. (Çev. Emra Durukan), Değişim Yayınları.

Tahir Gürçağlar, Ş. (2011). Çevirinin ABC's., İstanbul: Say Yayınları.

Toury, G. (1998). A Handful of Paragraphs on 'Translation' and 'Norms. (ed.Christina Schäffner), Translation and Norms. Clevedon etc., Current Issues in Language \& Society, ss. 10-32.

(1995). Descriptive Translation Studies and Beyond. John Benjamins B.V.

Yazıcı, M. (2010). Çeviribilimin Temel Kavram ve Kuramları. İstanbul: Multilingual Yayınları.

Yücel, F. (2007). Tarihsel ve Kuramsal Açıdan Çeviri Edimi, Ankara: Dost Kitabevi. 